AGRONOMY

\title{
Chemical and Non-chemical Method of Weed Management in Blackgram (Vigna mungo L.) in North Eastern Zone of Tamil Nadu
}

\author{
C. Sivakumar ${ }^{1}$, Krishnaveni ${ }^{1 *}$, A. Rajendran ${ }^{2}$, R. Eniya ${ }^{1}$, S. Hemalatha ${ }^{1}$, Vennila, G. ${ }^{1}$ and \\ Pandiyan, $\mathrm{M}^{3}$
}

${ }^{1}$ Agricultural College and Research Institute, Tamil Nadu Agricultural University, Vazhavachanur, Thiruvannamalai District, Tamil Nadu, India

${ }^{2}$ Agricultural College and Research Institute, Tamil Nadu Agricultural University, Echankottai, Tanjavur, Tamil Nadu, India ${ }^{3}$ Department of Plant Breeding and Genetics, Tamil Nadu Agricultural University, Echankottai, Tanjavur, Tamil Nadu, India

"Corresponding author: venikrishna25@yahoo.co.in (ORCID ID: 0000-0002-4860-5741)

Paper No. 804

Received: $18-06-2019$

Revised: $13-10-2019$

Accepted: $30-11-2019$

\section{ABSTRACT}

\begin{abstract}
Pulse crops are grown in different cropping systems as a sole crop, catch crop, mixed crop, intercrop and sequential crop in different cropping systems followed by farmers. The crops are facing weed infestation during its entire life cycle from seed to seed. The weed management in appropriate time will increase the yield. In the present study, the dominant weeds species like Echinochloa colona, Cyperus rotundus, Commelina benghalensis and Phyllanthus spp. were observed. Among the treatment methods, application of both pre emergence (pendimethalin @ $1 \mathrm{~kg}$ a.i ha-1) at 3 DAS (days after sowing) + post emergence (Quizalofop-p- ethyl @ $50 \mathrm{~g} . \mathrm{i} \mathrm{ha}^{-1)}$ at 25 DAS recorded the minimum weed density and shown weed control efficiency of 97.32 per cent at 45 DAS and 97.94 per cent at 60 DAS with seed yield of 1004.1 $\mathrm{kg} \mathrm{ha}^{-1}$. The non chemical method like sugarcane trash mulching decreased the weed density but the complete weed control efficiency was not observed. The herbicidal treatments significantly reduced the weed biomass compared to weedy check.
\end{abstract}

\section{Highlights}

( Timely application of pre emergence (pendimethalin @ $1 \mathrm{~kg}$ a.i ha ${ }^{-1}$ ) at 3 DAS (days after sowing) + post emergence (Quizalofop-p- ethyl @ $50 \mathrm{~g} . \mathrm{i} \mathrm{ha}^{-1)}$ at 25 DAS was very effective in controlling weeds and also increased the seed yield in greengram ecosystem which eliminates the scarcity of labour.

Keywords: Black gram, Pendimethalin, Quizalofop-p- ethyl, Weed density, Weed control efficiency, Mulching, sugarcane trash, Plastic mulch, Economics

Blackgram is an important crop among the kharif pulses, which is usually grown in marginal and sub-marginal lands without any weed management practices. The blackgram production was 14 lakh tonnes in an area of 31 lakh hectare area with an average productivity of $45161 \mathrm{~kg} \mathrm{ha}^{-1}$ in India during 2011-12. Blackgram has been widely cultivated in tropical and sub tropical countries like India, Pakistan, Sri Lanka, Myanmar and south-east Asian countries. In India, Madhya Pradesh, Andhra Pradesh, Bihar, Maharashtra, Punjab, Haryana, Tamil Nadu Uttar Pradesh, West Bengal and Karnataka are important for blackgram cultivation.
Blackgram is a contains all the nutrients which includes protein of $25-26 \%, 60 \%$ of carbohydrates and fat of $1.5 \%$ in addition to amino acids ,minerals, and vitamins. The leguminous crop has all the essential nutrients which will act as a fertilizer and also has the ability to fix atmospheric nitrogen through bacterial symbiosis which ultimately restores the soil fertility. Presently, the productivity and production of the black gram are not only diminishing but the area is also reducing despite being largest producer of blackgram. There are many reasons like discarded and hungry and soils, improper fertilization lack of promising cultivar, 
pest and diseases infestation, and poor weed management is one of the most important yield limiting factors due to crop - weed competition.

\section{Crop-weed competition}

The shortest life cycle of pulse crop subjected to crop weed competition during critical period of its stages, and results reduction of yield. The weeds will compete with crop for soil nutrients, light, moisture, space and water for its growth and development. The crop plants have diffentability to compete with weeds (Moolani and Sachan 2007). The critical period for weed competition in blackgram was 20 - 40 DAS, which results yield losses from 40 -85 $\%$ in Pantnagar, Uttaranchal (Sharma and Yadav 2006), Kushwah and Vyas (2005) and Nawanshahr in Punjab (Parvender et al. 2006).

Based on the intensity and nature of weed flora, $30-50 \%$ yield reduction was observed at Jabalpur, Madhya Pradesh Mishra and Bhanu (2006). Sardana et al. (2006) reported that the blackgram crop faces severe weed competition due to its slow initial growth and lack of effective control measures at Nawanshahr, Panjab. Chattha et al. (2007) conducted a field study in Islamabad, Pakistan and found that the critical period of crop weed competition in blackgram are 20-40 days. Singh (2011) reported that the critical period of crop -weed competition in summer blackgram was 10 - 40 days at Ludhiana, Punjab, whereas as 25-35 days after sowing and yield loss of $41.6 \%$ (Randhawa et al. 2002).

\section{Associated weed flora}

Blackgram is generally grown in kharif season as well as summer and is found infested with both broad leaved and grassy weeds. The diversity weed flora in the crop field depends on environmental factors, types of soil, management practices,, which requires proper identification of weed species to execute the exact effective control measures for weeds. Hemlata et al. (2012) found the dominant weed species viz., Celosia argente, Cynodon daclylon, Phyllanthus niruri and Cyperus rotundus throughout the crop growth period of black gram at Raipur, Chhattisgarh. There were many weeds, particularly Echinochloa spp. compete effectively with crop for soil moisture and fertility and reduces the yield up to $53 \%$ at Baptala, Andhra Pradesh (Begum and Rao 2006).

\section{Non chemical method of weed Management}

Among the different non chemical methods of weed control like manual weeding is the conventional practice adopted in various crops including blackgram. The weed management through hand weeding at 20 and 40 DAS resulted maximum number of pods per plant, 1000 seed weight, seed yield of $17.15 \mathrm{q} \mathrm{ha}^{-1}$ with weed control efficiency of $63.07 \%$ in blackgram at Palampur, Himachal Pradesh (Kumar et al. 2005). Raman and Krishnamoorthy (2005). found that the weed biomass and weed count were minimum due to twice hand weeding on 20 and 40 DAS followed by application of pendimethalin @ $1.0 \mathrm{~kg} \mathrm{ha}^{-1}$. Two hand weeding at 25 and 40 days after sowing resulted in the lowest weed population in black gram at Nawanshahr, in Panjab (Parvender et al. 2006).

\section{Chemical Method of weed Management}

The common method of hand weeding employed to control weeds in blackgram is not only laborious but very expensive as well. For effective control of weeds in blackgram, chemical weed management in blackgram has been found effective and economical. But, the unavailability of manpower at right time and high labour cost are limiting factors by hand weeding (Chand et al. 2004). Meyyappan and Kathiresan (2005) reported that application of alachlor@ $3 \mathrm{~kg} \mathrm{ha}^{-1}$ followed by hand weeding at 30 DAS was effective in reducing the density and dry weight of weeds like Echinochloa colona, Trianthema portulacastrum, Cynodon dactylon and Cleome viscose in black gram in Tamil Nadu. Sharma and Yadav. (2006) found that seed yield was the highest for two hand weeding at 20 and 40 DAS, pre-emergence application of alachlor at $1.5 \mathrm{~kg} \mathrm{ha}^{-1}$ with one hand weeding and pendimethalin at $0.75 \mathrm{~kg} \mathrm{ha}^{-1}$ with one hand weeding than weedy check in blackgram at Pantnagar, Uttaranchal.

Kumar and Angiras (2005) reported that the weed control efficacy for the application of pendimethalin @ $1.50 \mathrm{~kg} \mathrm{ha}^{-1}$ in combination with raised bed planting was found to be effective against the dominant weeds like Echinochloa colona, Cyperus iria, Digitaria sanguinalis, Panicum dichotomiflorum, Commelina benghalensis, Polygonum alatum and Ageratum conyzoides and also increased the seed yield of black gram under different planting 
methods at Palampur, Himachal Pradesh, India. Sharma and Yadav (2006) found that grain yield in blackgram was the highest for two hand weeding given at 20 and $40 \mathrm{DAS}$, pre-emergence application of alachlor @ $1.5 \mathrm{~kg} \mathrm{ha}^{-1}$ with one hand weeding and pendimethalin @ $0.75 \mathrm{~kg} \mathrm{ha}^{-1}$ with one hand weeding than weedy check in blackgram at Pantnagar, Uttaranchal.

The density and dry weight of weeds were significantly reduced by application of quizalofop-pethyl @ 50 and $75 \mathrm{~g}$ a.i ha ${ }^{-1}$ compared to un-weeded check and considering the economics, pendimethalin @ $1.0 \mathrm{~kg}$ a. i ha-1 was found to be cost effective in rice-fallow blackgram at Hyderabad, Andhra Pradesh. Naidu et al. (2012). Rajput et al. (2014) reported that the application of pre emergence herbicide i.e. pendimethalin @ $1000 \mathrm{~g}$ and $1500 \mathrm{~g}$ a.i ha $^{-1}$ had minimized the monocot and dicot weeds. Post -emergence application of quizalofop-p-ethyl @ $50 \mathrm{~g}$ and 75 a.i $\mathrm{g} \mathrm{ha}^{-1}$ had shown significant effect on weed dry weight in blackgram at Akola, Maharashra. Patel et al. (2014) found that seed and haulm yield of blackgram was significantly higher in pre-emergence application of pendimethalin @ $1000 \mathrm{~g}$ a.i ha-1 which was at par with weeding carried out at 20 and 40 DAS.at Anand, Gujarat. In the point of economics, Velayudham (2007) found that the pre-emergence application of pendimethalin @ $0.75 \mathrm{~kg}$ a. i./ha + hand weeding on 40 DAS + normal seed rate recorded higher seed yield of 753 $\mathrm{kg} / \mathrm{ha}$ and highest benefit - cost ratio in blackgram.

\section{MATERIALS AND METHODS}

The field experiment was conducted at Agricultural College and Research institute, vazhavachanur during summer season, 2018 in the blackgram variety: VBN-8.. The experiment was laid out in Randomized Block Design during with three replications. The detail of the treatment follows

\section{Treatment details}

\begin{tabular}{|c|c|}
\hline Treatments & Details \\
\hline $\mathrm{T} 1$ & Control \\
\hline $\mathrm{T} 2$ & $\begin{array}{l}\text { Pre emergence (pendimethalin @ } 1 \text { kg a. i ha }{ }^{-1} \text { ) } \\
\text { at } 3 \text { DAS }\end{array}$ \\
\hline T3 & $\begin{array}{l}\text { Pre emergence (pendimethalin @ } 1 \mathrm{~kg} \text { a. i ha } \mathrm{h}^{-1} \text { ) } \\
\text { at } 3 \text { DAS + Hand weeding at } 25 \text { DAS }\end{array}$ \\
\hline $\mathrm{T} 4$ & $\begin{array}{l}\text { Post emergence (Quizalofop-p- ethyl @ } 50 \mathrm{~g} \text { a. } \\
\text { i ha-1) at } 25 \text { DAS }\end{array}$ \\
\hline
\end{tabular}

Pre emergence (pendimethalin @ 1 kg a. i ha ${ }^{-1}$ ) at 3DAS +

Post emergence (Quizalofop-p- ethyl @ $50 \mathrm{~g}$ a. $\left.\mathrm{i} \mathrm{ha}^{-1}\right)$ at 25 DAS

T6 Polythene sheet mulching

T7 Sugarcane trash mulching

The crop was management as per the crop production manual of TNAU except weed management practices. The biometric observations were made on weeds and crop are presented below

\section{Weed density}

The quadrate of $1 \mathrm{~m}^{2}$ (square meter) was randomly placed at three places in each plot and then the species wise and total weed count was recorded.

\section{Weed biomass}

The weed biomass was at 45, 60 DAS. All the associated weeds were collected were kept in paper bags and dried in hot air oven at $160^{\circ} \mathrm{C}$ for 24 hours and weighed dry matter was converted into $\mathrm{g} \mathrm{m}^{-2}$.

\section{Weed control efficiency (\%)}

Weed control efficiency (\%) by Mani et al. (1973) was calculated based on the following formula:

Dry weight of weeds in control plot -

W.C.E. $=\frac{\text { Dry weight of weeds in treated plot }}{\text { Dry weight of weeds in control plot }} \times 100$

\section{Crop plant height}

The height of five randomly selected plants was measured from the ground level to the base of apical bud with the help of a meter scale at 15, 30, 45, 60 DAS mean height was calculated.

\section{Number of branches per crop plant}

The number of basal branches arising from main shoot was counted in all five randomly marked plants at 15, 30, 45, 60 DAS and finally at harvest and then mean was determined for each stage.

\section{Crop Leaf area index (LAI)}

The leaves from five selected plants drawn for biomass observation were used for measuring leaf area. The leaf area index (LAI) was determined plot 
wise for each observation in all plots by using the following formula:

$$
\mathrm{LAI}=\frac{\text { Total leaf area }(\mathrm{L})}{\text { Ground area covered }(\mathrm{P})}
$$

Where, $\mathrm{A}=$ leaf area $\left(\mathrm{m}^{-2}\right), \mathrm{P}=$ Ground area $\left(\mathrm{m}^{-2}\right)$

\section{Dry weight of plant}

Five plants were randomly removed from each plot at 45, 60 DAS and at harvest to study the total dry weight and the total dry weight per plant was determined by dividing the weight of plant samples with five and then the values were converted into total dry weight $/ \mathrm{m}^{2}$ by multiplying with plant population $/ \mathrm{m}^{2}$.

\section{Number of Pods per plant}

The pods present in all five sample plants of each plot were removed and their number was counted. Then mean was calculated.

\section{Number of seeds per pod}

The seeds were separated from the 5 sampled plants in each plot and their number was counted.

\section{Test -weight (100 seed weight)}

From the lot of threshed clean seeds of each plot, random seed sample was taken and one hundred seeds were counted from the samples of each plot and weight of seeds was recorded on an electronic balance.

\section{Seed Yield}

The weight of clean seeds obtained from each plot was recorded on double pan balance. Finally, the seed yield plot ${ }^{-1}$ was converted into yield ha- ${ }^{-1}$ by multiplying with appropriate conversion factor.

\section{Stover Yield}

Stover yield was determined by subtracting the seed yield from the biological yield of each net plot under a particular treatment. Then, the values were converted into Stover yields ha ${ }^{-1}$ by using the same conversion factor

\section{Harvest Index (HI)}

It refers to the ratio of economic yield (seed yield) to the biological (seed + stover ) yield under a particular treatment and it is expressed in percentage. It was computed by using the following formula:

$$
\text { HI }(\%)=\frac{\text { Economic yield }}{\text { Biological yield }} \times 100
$$

\section{Cost of cultivation}

The total cost of cultivation incurred in different agro - inputs and agricultural operations to raise the crop under a particular treatment was worked out on the basis of existing market price of the input, power and wages etc.

\section{Gross monetary returns (GMR)}

The GMR is the monetary value of the total produce of a particular treatment as per existing market rate. It was computed treatment wise on per hectare area basis.

\section{Net monetary returns (NMR)}

The NMR under a particular treatment was determined by subtracting the cost of cultivation per hectare from GMR per hectare of the same treatment.

\section{Profitability (Benefit -cost ratio)}

It gives an indicative of the true monetary gains over every rupee of investment under a particular treatment. I $t$ is worked out by using the following formula:

$$
\text { Benefit cost ratio }=\frac{\text { Gross return }\left(\text { Rs. ha }{ }^{-1}\right)}{\text { Cost of cultivation }\left(\text { Rs. ha }{ }^{-1}\right)}
$$

\section{RESULTS AND DISCUSSION}

The data recorded on weeds, crop growth parameters, yield attributing characters and yield were tabulated and subjected to their statistical analysis.

\section{Associated weed flora}

The observations on population of major weeds were recorded in the blackgram experimental field and presented in Table 1. Hemlata et al. (2012) found the dominant weed species viz., Celosia argente, Cynodon daclylon, Phyllanthus niruri and Cyperus rotundus throughout the crop growth period of black gram. 
Table 1: The Weed flora in black gram experimental field

\begin{tabular}{llll}
\hline $\begin{array}{l}\text { Sl. } \\
\text { No. }\end{array}$ & Scientific name & $\begin{array}{l}\text { Common } \\
\text { name }\end{array}$ & Family \\
\hline 1 & Cyperus rotundus (L.) & $\begin{array}{l}\text { Purple nut } \\
\text { sedge }\end{array}$ & Cyperaceae \\
2 & Echinochloa colona (L.) & Jungal rice & Poaceae \\
3 & $\begin{array}{l}\text { Commelina } \\
\text { benghalensis (L.) }\end{array}$ & $\begin{array}{l}\text { Bengal day } \\
\text { flower }\end{array}$ & Commelinaceae \\
4 & Phyllanthus neruri (L.) & Stonebreaker & Euphorbiaceae \\
5 & $\begin{array}{l}\text { Parthenium } \\
\text { hysterophorus }\end{array}$ & $\begin{array}{l}\text { Congress } \\
\text { weed }\end{array}$ & Asteracea \\
\hline
\end{tabular}

\section{Weed density}

The weed density at 15, 30, 45 and 60 days after sowing (DAS) and at harvest have been presented in the Table 2.

At 15 DAS, application of pre-emergence Pre emergence (pendimethalin @ $1 \mathrm{~kg}$ a.i ha-1) at 3 DAS + Post emergence (Quizalofop-p- ethyl @ 50 g a. i $\left.\mathrm{ha}^{-1}\right)$ at 15 DAS $\left(\mathrm{T}_{5}\right)$ recorded lower weed count 3.08 per $\mathbf{m}^{2}$ ( Table 2) compared to weed check $\left(\mathrm{T}_{1}\right)$ with 294.75 per $\mathbf{~ m}^{2}$.

Table 2: Weed density in black gram experimental field at 15, 30, 45 and 60 DAS

\begin{tabular}{lllll}
\hline \multirow{2}{*}{ Treatments } & \multicolumn{4}{c}{ Weed density $\left(\mathbf{m}^{2}\right)$} \\
\cline { 2 - 5 } & 15 DAS & 30 DAS & 45 DAS & 60 DAS \\
\hline T1 & 294.75 & 377.58 & 538.5 & 400.41 \\
& $(17.18)$ & $(19.44)$ & $(23.21)$ & $(20.22)$ \\
T2 & 3.5 & 12.25 & 13.91 & 16.08 \\
& $(1.99)$ & $(3.56)$ & $(3.79)$ & $(4.07)$ \\
T3 & $3.33(1.95)$ & $5.16(2.37)$ & $3.33(1.95)$ & $8.33(2.97)$ \\
T4 & 285.66 & 23.766 & $3.66(2.03)$ & $11.5(3.46)$ \\
& $(16.89)$ & $(4.92)$ & & \\
T5 & $3.08(1.88)$ & $2.41(1.70)$ & $3.16(1.91)$ & $6.08(2.56)$ \\
T6 & 125.66 & 137.66 & 136.66 & 141.58 \\
& $(11.23)$ & $(11.75)$ & $(11.71)$ & $(11.91)$ \\
T7 & $93.33(9.68)$ & $87.91(9.40)$ & $87.58(9.22)$ & 92.16 \\
& & & & $(9.62)$ \\
SED & 4.579 .61 & 0.150 .32 & 3.246 .81 & 4.108 .61 \\
CD (P=0.05) & & & & \\
\hline
\end{tabular}

T1-Control (weed check),T2-Pre emergence (pendimethalin @ 1 $\mathrm{kg}$ a. $\mathrm{i} \mathrm{ha-1)}$ at 3 DAS,T3-Pre emergence (pendimethalin @ $1 \mathrm{~kg}$ a. $i$ ha-1) at 3 DAS + Hand weeding at 25 DAS,T4-Post emergence (Quizalofop-p-ethyl @ $50 \mathrm{~g}$ a. i ha $a^{-1}$ ) at 25 DAS,T5-Pre emergence (pendimethalin@ $1 \mathrm{~kg}$ a. $i \mathrm{ha}^{-1}$ ) at 3DAS +Post emergence (Quizalofop-p-ethyl@50ga.i ha-1) at 25 DAS,T6-Polythene sheet mulching,T7-Sugarcane trash mulching.
At 30 DAS, Among all the treatments, application of pre-emergence Pre emergence (pendimethalin @ 1 $\mathrm{kg}$ a.i ha ${ }^{-1}$ ) at 3 DAS + Post emergence (Quizalofop-pethyl@ $50 \mathrm{~g}$ a. i ha-1) at 15 DAS $\left(\mathrm{T}_{5}\right)$ found to be less weed density (2.41 per $\mathrm{m}^{2}$ ) compared to other treatments followed by Pre emergence (pendimethalin@ $1 \mathrm{~kg}$ a. i ha ${ }^{-1}$ ) at 3 DAS + Hand weeding $\left(\mathrm{T}_{3}\right)$.Among all the treatments, weedy check recorded maximum weed density (377.58 per $\mathrm{m}^{2}$ ) (T1). Similar trend in weed intensity was recorded at 45 DAS and 60 DAS. Naidu et al. (2012) stated that the same findings that the density and dry weight of weeds were reduced by application of quizalofop-p-ethyl @ 50 and 75 g a.i ha ${ }^{-1}$ compared to un-weeded check

\section{Total Weed Dry Weight and Weed control efficiency}

The data on dry weight of total weeds are presented in Table 4 . The weed dry weight was significantly lower in application of pre-emergence Pre emergence (pendimethalin@ $1 \mathrm{~kg}$ a.i ha ${ }^{-1}$ ) at 3 DAS + Post emergence (Quizalofop-p- ethyl @ $50 \mathrm{~g} \mathrm{a.} \mathrm{i} \mathrm{ha}^{-1}$ ) at 15 DAS $\left(\mathrm{T}_{5}\right)$ at 45 with $1.15\left(\mathrm{~g} / \mathrm{m}^{2}\right)$ and 60 DAS $(0.83$ $\mathrm{g} / \mathrm{m}^{2}$ ) when compared to control. Whereas, the weed control efficiency was maximum 97.32 per cent and 97.94 per cent due to application of pre-emergence Pre emergence (pendimethalin @ $1 \mathrm{~kg}$ a.i ha ${ }^{-1}$ ) at 3 DAS + Post emergence (Quizalofop-p- ethyl @ 50 $\mathrm{g}$ a. i ha $\left.{ }^{-1}\right)$ at 15 DAS $\left(\mathrm{T}_{5}\right)$ when compared other non chemical and chemical treatment methods. The maximum total weed dry weight $\left(\mathrm{g} / \mathrm{m}^{2}\right)$ and lower weed control efficiency (\%) at 45, 60 DAS and harvest stage was found in $\mathrm{T}_{1}$ weed check (control), Meyyappan and Kathiresan (2005) reported the similar findins in weed management in Blackgram.

Table 3: Effect of different treatments on total weed dry weight $\left(\mathrm{g} / \mathrm{m}^{2}\right)$ and weed control efficiency $(\%)$ at 45, 60 DAS and harvest stage

\begin{tabular}{lllllll}
\hline & \multicolumn{2}{c}{$\begin{array}{c}\text { Total weed dry weight } \\
\text { Treat- } \\
\text { ments }\end{array}$} & \multicolumn{3}{c}{$\begin{array}{c}\text { W/m² } \\
\text { need control } \\
\text { efficiency }(\%)\end{array}$} \\
\cline { 2 - 7 } & 45 DAS & 60 DAS & $\begin{array}{l}\text { At } \\
\text { Harvest }\end{array}$ & $\begin{array}{l}\text { 45 } \\
\text { DAS }\end{array}$ & $\begin{array}{l}\text { 60 } \\
\text { DAS }\end{array}$ & $\begin{array}{l}\text { At } \\
\text { Harvest }\end{array}$ \\
\hline T1 & 43.06 & 40.33 & 38 & - & - & - \\
& $(6.17)$ & $(5.52)$ & $(5.72)$ & & & \\
T2 & 2.04 & 1.9 & 1.5 & 95.20 & 88.69 & 95.97 \\
& $(1.52)$ & $(1.47)$ & $(1.36)$ & & &
\end{tabular}

${ }^{*}$ Figures in parenthesis is transformed values. 


\begin{tabular}{llllllll} 
T3 & 1.87 & 1.73 & 1.33 & 95.65 & 95.71 & 96.57 \\
& $(1.51)$ & $(1.46)$ & $(1.33)$ & & & \\
T4 & 10.68 & 9.66 & 9.16 & 75.19 & 76.04 & 75.89 \\
& $(3.32)$ & $(3.17)$ & $(3.09)$ & & & \\
T5 & 1.15 & 0.83 & 0.5 & 97.32 & 97.94 & 98.68 \\
& $(1.27)$ & $(1.13)$ & $(0.98)$ & & & \\
T6 & 24.2 & 22.6 & 21.7 & 43.79 & 43.81 & 42.89 \\
& $(7.3)$ & $(7.03)$ & $(6.88)$ & & & \\
T7 & 21.99 & 20.66 & 19 & 48.93 & 48.77 & 50.00 \\
& $(4.72)$ & $(4.5)$ & $(4.40)$ & & & \\
SED & 1.92 & 1.91 & 1.86 & - & - & - \\
CD $(\mathrm{p}=$ & 4.03 & 4.01 & 3.92 & & & \\
$0.05)$ & & & & & & \\
\hline
\end{tabular}

T1- Control ( weed check),T2-Pre emergence (pendimethalin @ 1 $\mathrm{kg}$ a. $\mathrm{i} \mathrm{ha} \mathrm{h}^{-1}$ ) at 3 DAS,T3-Pre emergence (pendimethalin@ $1 \mathrm{~kg}$ a. $\left.i \mathrm{ha}^{-1}\right)$ at $3 \mathrm{DAS}+$ Hand weeding at $25 \mathrm{DAS}, \mathrm{T4}$-Post emergence (Quizalofop-p-ethyl @ $50 \mathrm{~g}$ a. $i \mathrm{ha}^{-1}$ ) at 25 DAS,T5-Pre emergence (pendimethalin@1 $\mathrm{kg}$ a. i ha $\mathrm{a}^{-1}$ ) at 3DAS + Post emergence (Quizalofop-p-ethyl@ $50 \mathrm{~g}$ a. i ha ${ }^{-1}$ ) at 25 DAS,T6-Polythene sheet mulching, T7-Sugarcane trash mulching,

Figures in parenthesis is transformed values

\section{Crop Plant height $(\mathrm{cm})$}

The plant height at various stages of crop growth was calculated $\mathrm{d}$ and presented in Table 4 . The plant height of blackgram at 15 DAS was maximum the Polythene sheet mulching $\left(\mathrm{T}_{6}\right)$ and sugarcane mulching (on par value) $\left(\mathrm{T}_{7}\right)$ followed by application of pre-emergence Pre emergence (pendimethalin @ 1 $\mathrm{kg}$ a.i ha ${ }^{-1}$ ) at 3 DAS + Post emergence (Quizalofop-pethyl @ $50 \mathrm{~g}$ a. i ha-1) at 15 DAS $\left(\mathrm{T}_{5}\right)$. But, at 30 DAS, 45 DAS and 60 DAS was maximum under application of pre-emergence Pre emergence (pendimethalin@ $1 \mathrm{~kg}$ a.i ha-1) at 3 DAS + Post emergence (Quizalofop-p- ethyl @ $50 \mathrm{~g} \mathrm{a.} \mathrm{i} \mathrm{ha}{ }^{-1}$ ) at 15 DAS $\left(\mathrm{T}_{5}\right)$ with $30.28,37.6,38.66 \mathrm{~cm}$, respectively. The weedy check $\left(\mathrm{T}_{1}\right)$ was recorded minimum plant height of $24.26 \mathrm{~cm}$ and $29.13 \mathrm{~cm}$ DAS and 60 DAS respectively.

Table 4: Effect of different treatments on plant height (cm) at 15, 30, 45 and 60 DAS

\begin{tabular}{lllll}
\hline Treatments & \multicolumn{4}{c}{ Plant height(cm) } \\
\cline { 2 - 5 } & 15 DAS & 30 DAS & 45 DAS & 60 DAS \\
\hline T1 & 11.48 & 20.47 & 24.26 & 29.13 \\
T2 & 15.93 & 22.96 & 26.2 & 31.03 \\
T3 & 12.88 & 24.35 & 26.73 & 31.53 \\
T4 & 15.76 & 24.02 & 26.53 & 31.26 \\
T5 & 17.21 & 30.28 & 37.6 & 38.66
\end{tabular}

\begin{tabular}{lllll} 
T6 & 18.28 & 30.1 & 36.4 & 36.8 \\
T7 & 18.09 & 24.70 & 27.5 & 31.66 \\
SED & 0.36 & 0.532348 & 0.808267 & 0.483506 \\
$\mathrm{CD}(\mathrm{p}=0.05)$ & 0.776071 & 1.118463 & 1.69817 & 1.015846 \\
\hline
\end{tabular}

T1-Control ( weed check),T2-Pre emergence (pendimethalin@1 $\mathrm{kg}$ a. $\mathrm{i} \mathrm{ha} \mathrm{H}^{-1}$ ) at 3 DAS,T3-Pre emergence (pendimethalin @ $1 \mathrm{~kg}$ a. $\left.i \mathrm{ha}^{-1}\right)$ at $3 \mathrm{DAS}+$ Hand weeding at $25 \mathrm{DAS}$, T4-Post emergence (Quizalofop-p-ethyl @ $50 \mathrm{~g}$ a. $i \mathrm{ha}^{-1}$ ) at 25 DAS, T5-Pre emergence (pendimethalin@1 $\mathrm{kg} a . i \mathrm{ha}^{-1}$ ) at 3DAS + Post emergence (Quizalofop-p-ethyl @50 g a. i ha ${ }^{-1}$ ) at 25 DAS, T6-Polythene sheet mulching, T7-Sugarcane trash mulching.

\section{Leaf area index}

At 30 and 45 DAS, the leaf area index was not significant under different treatments. At 60 DAS, application of pre-emergence (pendimethalin @ $1 \mathrm{~kg}$ a.i ha ${ }^{-1}$ ) at 3 DAS + Post emergence (Quizalofop-pethyl @ $50 \mathrm{~g}$ a. i ha-1) at 15 DAS $\left(\mathrm{T}_{5}\right)$ has recorded the highest leaf area index was recorded followed by Pre emergence (pendimethalin @ $1 \mathrm{~kg} \mathrm{a} . \mathrm{i} \mathrm{ha}^{-1}$ ) at 3 DAS + Hand weeding at 25 DAS $\left(\mathrm{T}_{3}\right)$. The lowest leaf area was recorded under weedy check (2.0) followed by sugarcane and polythene mulching with value of 2.7 and 2.9 at 60 DAS (Table 5).

\section{Number of branches per plant}

The observations on number of branches per plant recorded at 45, 60 DAS and harvest and presented in Table - revealed difference among various treatments. At 60 DAS and at harvest the number of branches plant ${ }^{-1}$ were the highest under application of pre-emergence (pendimethalin @ $1 \mathrm{~kg}$ a.i ha-1) at 3 DAS + Post emergence (Quizalofop-p- ethyl @ 50 g a. i ha-1) at 15 DAS $\left(\mathrm{T}_{5}\right)$ with 2.43 nos per plant and lowest no. of branches recorded in control plot (2.08) at 60 DAS.

\section{Plant dry weight}

The data on dry weight of plant at successive growth stages at 45, 60 DAS and at harvest were varied by different treatments are presented in Table 5. At 45 and 60 DAS, plant dry weight was maximum in application of pre-emergence (pendimethalin @ $1 \mathrm{~kg}$ a.i ha-1 ${ }^{-1}$ ) at 3 DAS + Post emergence (Quizalofop-pethyl@ $50 \mathrm{~g}$ a. i ha-1) at 15 DAS $\left(\mathrm{T}_{5}\right)$ with153.8, $534.6, .550 .9 \mathrm{~g} / \mathrm{m}^{2}$ at $45 \mathrm{DAS}, 60 \mathrm{DAS}$ and harvest stage respectively followed by sugarcane $\left(T_{7}\right.$ and polythene mulching $\left(\mathrm{T}_{6}\right)$ recorded the plant dry weight of $475.5,463.5 \mathrm{~g} / \mathrm{m}^{2}$ respectively compared 
Table 5: Effect of different treatment on leaf area index and number of branches per plant and plant dry weight $\left(\mathrm{g} / \mathrm{m}^{2}\right)$ at different stages of crop

\begin{tabular}{|c|c|c|c|c|c|c|c|c|c|}
\hline \multirow{2}{*}{ Treatments } & \multicolumn{3}{|c|}{ Leaf area index (LAI) } & \multicolumn{3}{|c|}{ Number of branches plant ${ }^{-1}$} & \multicolumn{3}{|c|}{ Plant dry weight $\left(\mathrm{g} / \mathrm{m}^{2}\right)$} \\
\hline & 30 DAS & 45 DAS & 60 DAS & 45 DAS & 60 DAS & At harvest & 45 DAS & 60DAS & At Harvest \\
\hline $\mathrm{T} 1$ & 0.53 & 1.97 & 2.0 & 1.98 & 2.08 & 2.50 & 94 & 365.8 & 380.2 \\
\hline $\mathrm{T} 2$ & 0.68 & 2.23 & 2.30 & 2.17 & 2.26 & 2.59 & 102 & 453 & 460 \\
\hline T3 & 0.84 & 2.47 & 3.0 & 1.98 & 2.34 & 2.61 & 139.84 & 490 & 501.2 \\
\hline $\mathrm{T} 4$ & 0.73 & 2.27 & 2.58 & 1.92 & 2.39 & 2.57 & 72.8 & 390.5 & 405.7 \\
\hline T5 & 0.86 & 2.83 & 3.5 & 1.95 & 2.43 & 2.84 & 153.8 & 534.6 & 550.9 \\
\hline T6 & 0.82 & 2.39 & 2.9 & 1.91 & 2.26 & 2.73 & 110.7 & 430.4 & 463.5 \\
\hline $\mathrm{T} 7$ & 0.8 & 2.35 & 2.7 & 1.97 & 2. & 2.81 & 112.2 & 450.2 & 475.5 \\
\hline SED & 0.20 & 0.15 & 0.13 & 0.07 & 0.09 & 0.11 & 8.37 & 11.50 & 11.50 \\
\hline $\mathrm{CD}(\mathrm{p}=0.05)$ & 0.42 & 0.31 & 0.41 & 0.15 & 0.20 & 0.24 & 25.73 & 35.36 & 35.35 \\
\hline
\end{tabular}

T1-Control (weed check), T2-Pre emergence (pendimethalin @ $1 \mathrm{~kg} a . i \mathrm{ha} \mathrm{-}^{-1}$ ) at 3 DAS,T3-Pre emergence (pendimethalin @ $1 \mathrm{~kg} a . i \mathrm{ha}$ ) at 3 DAS + Hand weeding at 25 DAS,T4-Post emergence (Quizalofop-p-ethyl @ $50 \mathrm{~g}$ a. $i$ ha-1) at 25 DAS,T5-Pre emergence (pendimethalin@ $1 \mathrm{~kg} a . i \mathrm{ha}^{-1}$ ) at 3DAS +Post emergence (Quizalofop-p-ethyl @ $50 \mathrm{~g}$ a. $i \mathrm{ha}^{-1}$ ) at $25 \mathrm{DAS}$, T6-Polythene sheet mulching, T7-Sugarcane trash mulching.

Table 6: Effect of different treatments on number of pods plant ${ }^{-1,}$ Number of seeds pod $^{-1}$ and test weight (g), Seed yield $\left(\mathrm{kg} \mathrm{ha}^{-1}\right)$, Stover Yield $\left(\mathrm{kg} \mathrm{ha}^{-1}\right)$ and Harvest Index (\%)

\begin{tabular}{lllllll}
\hline Treatments & $\begin{array}{l}\text { Number of } \\
\text { pods/ plant }\end{array}$ & $\begin{array}{l}\text { Number of } \\
\text { seeds/ pods. }\end{array}$ & $\begin{array}{l}\text { Test } \\
\text { weight }(\mathbf{g})\end{array}$ & $\begin{array}{l}\text { Seed Yield } \mathbf{( k g} \\
\mathbf{h a}^{-1} \mathbf{)}\end{array}$ & $\begin{array}{l}\text { Stover Yield } \\
\mathbf{( k g ~ h a}^{-1} \mathbf{)}\end{array}$ & $\begin{array}{l}\text { Harvest Index } \\
(\mathbf{\%})\end{array}$ \\
\hline $\mathrm{T}_{1}$ & 3.17 & 2.39 & 2.14 & 512.50 & 789.50 & 30.97 \\
$\mathrm{~T}_{2}$ & 3.86 & 2.48 & 2.24 & 654.10 & 1079.16 & 36.25 \\
$\mathrm{~T}_{3}$ & 4.19 & 2.51 & 2.26 & 895.80 & 1658.33 & 37.05 \\
$\mathrm{~T}_{4}$ & 3.43 & 2.43 & 2.15 & 541.60 & 891.66 & 36.16 \\
$\mathrm{~T}_{5}$ & 4.45 & 2.91 & 2.31 & 1004.10 & 1875.00 & 39.12 \\
$\mathrm{~T}_{6}$ & 3.91 & 2.57 & 2.24 & 904.17 & 1304.17 & 37.50 \\
$\mathrm{~T}_{7}$ & 4.23 & 2.59 & 2.26 & 925.00 & 1470.83 & 38.50 \\
$\mathrm{SED}$ & 0.41 & 0.05 & 0.01 & 95.64 & 127.37 & 0.43 \\
$\mathrm{CD}(\mathrm{p}=0.05)$ & 0.86 & 0.12 & 0.04 & 200.94 & 267.60 & 1.3 \\
\hline
\end{tabular}

T1- Control (weed check),T2-Pre emergence (pendimethalin @ $1 \mathrm{~kg} a . i \mathrm{ha} \mathrm{a}^{-1}$ ) at 3 DAS,T3-Pre emergence (pendimethalin @ $1 \mathrm{~kg}$ a. i ha ${ }^{-1}$ ) at 3 DAS + Hand weeding at 25 DAS, T4-Post emergence (Quizalofop-p-ethyl @ $50 \mathrm{~g}$ a. $i$ ha ${ }^{-1}$ ) at 25 DAS,T5-Pre emergence (pendimethalin@ $1 \mathrm{~kg}$ a. $i \mathrm{ha}^{-1}$ ) at 3DAS +Post emergence (Quizalofop-p-ethyl @ $50 \mathrm{~g}$ a. $i$ ha $\mathrm{a}^{-1}$ ) at 25 DAS,T6-Polythene sheet mulching, T7-Sugarcane trash mulching.

to other treatments. The lowest plant dry weight was recorded under weedy check $\left(380.2 \mathrm{~g} / \mathrm{m}^{2}\right)$ at harvest stage.

\section{Yield attributing characters}

\section{Number of pods per plant}

The mean number of pods/plant is presented in Table 6. It is evident from data that significant differences were observed in pods per plant due to different treatments. The treatment application of pre-emergence (pendimethalin @ $1 \mathrm{~kg}$ a.i ha ${ }^{-1}$ ) at
3 DAS + Post emergence (Quizalofop-p- ethyl @ 50 $\mathrm{g}$ a. i ha-1) at 15 DAS $\left(\mathrm{T}_{5}\right)$ gave significantly higher number of pods plant ${ }^{-1}$ (4.45) whereas the non chemical treatments like sugarcane mulching $\left(\mathrm{T}_{7}\right)$ shown 4.23 followed by post emergence Quizalofopp-ethyl 50 a.i ha-1 $\left(\mathrm{T}_{4}\right)$.

\section{Number of seeds per pod}

The data on average number of seeds per pod are presented in table, and depicted in figure it is evident from the data that significant difference was observed in seeds per pod due to different treatments. 
Application of pre-emergence (pendimethalin @ $1 \mathrm{~kg}$ a.i ha ${ }^{-1}$ ) at 3 DAS + Post emergence (Quizalofop-pethyl @ $50 \mathrm{~g}$ a. i ha-1 ${ }^{-1}$ at 15 DAS $\left(\mathrm{T}_{5}\right)$ recorded 2.91 pods per plant

\section{Test weight of 100 seeds}

The data on 100 seeds weight (Table 6) indicated that higher test weight $(2.33 \mathrm{~g})$ due to application of pre-emergence (pendimethalin @ $1 \mathrm{~kg} \mathrm{a.i} \mathrm{ha}^{-1}$ ) at 3 DAS + Post emergence (Quizalofop-p- ethyl @ 50 $\mathrm{g}$ a. $\left.\mathrm{i} \mathrm{ha}^{-1}\right)$ at $15 \mathrm{DAS}\left(\mathrm{T}_{5}\right)$ followed by $\mathrm{T}_{7}$-sugarcane mulching (2.26 g). Among all treatment control $\left(\mathrm{T}_{1}\right)$ has the lowest test weight $(2.13 \mathrm{~g})$.

\section{Seed yield}

The data pertaining to the seed yield of blackgram ( $\mathrm{kg} \mathrm{ha}^{-1}$ ) was significantly influenced due to application of herbicidal treatments are presented in Table -8. Among all the treatments, application of pre-emergence (pendimethalin @ $1 \mathrm{~kg}$ a.i ha-1) at 3 DAS + post emergence (Quizalofop-p- ethyl @ $50 \mathrm{~g}$ a. i ha $\left.{ }^{-1}\right)$ at 15 DAS $\left(T_{5}\right)$ recorded significantly the higher seed yield (1004 $\mathrm{kg} \mathrm{ha}^{-1}$ ) followed by polythene mulching $\left(\mathrm{T}_{6}\right)$ and sugarcane mulching ( $\mathrm{T}_{7}$ ) with seed yield of $904,925 \mathrm{~kg} \mathrm{ha}^{-1}$ respectively. The lowest yield recorded of $512 \mathrm{~kg} \mathrm{ha}^{-1}$ was recorded in $\mathrm{T}_{1}$ (weed check).

\section{Stover yield}

The stover yield data was presented in Table 7 . The stover yield has significant variation in straw with respect to different treatments. Generally, all the treatment practices registered significantly higher straw yield over weedy check (1162.5 $\mathrm{kg} \mathrm{ha-1}$ ), whereas application of pre-emergence (pendimethalin@ $1 \mathrm{~kg}$ a.i ha-1) at $3 \mathrm{DAS}+$ post emergence (Quizalofop - p- ethyl @ $50 \mathrm{~g}$ a. i ha-1) at 15 DAS $\left(T_{5}\right)$ recorded the highest amount of 1875 $\mathrm{kg} \mathrm{ha}^{-1}$. which was recorded significantly the higher straw yield over all the treatments followed $\mathrm{T}_{3}$ - pre emergence (pendimethalin @ $1 \mathrm{~kg}$ a. i ha-1) at 3 DAS + Hand weeding at 25 DAS (1658.33 $\left.\mathrm{kg} \mathrm{ha}^{-1}\right)$. Among the treatments, sugarcane mulching $\left(\mathrm{T}_{7}\right)$ and polythene mulching $\left(\mathrm{T}_{6}\right)$ recorded significantly higher straw yield than alone application of pendimethalin@ $1 \mathrm{~kg}$ a. i ha ${ }^{-1}$ at 3 DAS with 1079.16 $\mathrm{kg} \mathrm{ha}^{-1}$ and post emergence (Quizalofop-p- ethyl @ $50 \mathrm{~g}$ a. i ha-1) at 25 DAS with $891.66 \mathrm{~kg} \mathrm{ha}^{-1}$.

\section{Harvest index}

The ratio between economic yields to biological yield was affected by various weed control treatments (Table 7). The harvest index among various treatments varied from $0.36-0.39$ as against 0.30 in weedy check indicating that greater energy was diverted in product ion of straw in weedy check rather than seed while the herbicidal treatments and hand weeding, mulching had high coefficient for partitioning the photosynthetic production of seed and accordingly the higher harvest index was obtained under these treatments.

\section{Economics of the treatments}

The economic analysis of the treatments was done on per hectare basis, which includes cost of cultivation, gross monetary returns, net monetary returns and benefit cost ratio (Table 7). Considering the economics, pendimethalin @ 1.0 kg a. i ha ${ }^{-1}$ was found to be cost effective in rice-fallow blackgram by Naidu et al. (2012)

\section{Cost of cultivation}

Cost of cultivation was expressed treatment wise on the basis of current market price of various common and variable agro-inputs. The values thus obtained are presented in Table. Weedy check had the lowest cost of cultivation of ₹ $19,200 \mathrm{ha}^{-1}$. The highest cost of cultivation was recorded under polythene mulching with value of Rs.43,200 followed by pre emergence pendimethalin application @ 1 kg a. i ha $^{-1}$ at 3 DAS + Hand weeding cost about ₹ 25,920 followed by sugarcane trash mulching with cost of ₹ 24200 ha $^{-1}$.

\section{Gross monetary returns}

The value of economic produce (seed yield) was taken on the existing market rate in consideration for determining the gross monetary returns (GMR) under each treatment are presented in Table 7 . The GMR was minimum ( $₹ 25625$ ha $^{-1}$ ) in weedy check The GMR was maximum for the application of preemergence (pendimethalin @ $1 \mathrm{~kg}$ a.i ha ${ }^{-1}$ ) at 3 DAS + post emergence (Quizalofop - p- ethyl @ $50 \mathrm{~g}$ a. i ha-1) at 15 DAS with an amount of ₹ 50205 ha $^{-1}$ followed by Sugarcane trash mulching with return of ₹ 46250 and pre-emergence @ pendimethalin 1 $\mathrm{kg}$ a.i ha $\mathrm{h}^{-1}$ at $3 \mathrm{DAS}+$ Hand weeding with return ₹ 44790 ha $^{-1}$. 
Table 7: Economics of different weed control treatments in blackgram

\begin{tabular}{lllll}
\hline Treatments & Cost of cultivation (₹/ha) & Gross monetary return & Net monetary return & B:C Ratio \\
\hline T1 & 25625 & 6425 & $1.3: 1$ \\
T2 & 32700 & 10530 & $1.4: 1$ \\
T3 & 22170 & 44790 & 18870 & $1.7: 1$ \\
T4 & 25920 & 50205 & 3772 & $1.2: 1$ \\
T5 & 23308 & 45205 & 25427 & $2.05: 1$ \\
T6 & 24478 & 46250 & 2005 & $1.04: 1$ \\
T7 & 43200 & 22050 & $1.91: 1$
\end{tabular}

T1-Control (weed check),T2-Pre emergence (pendimethalin @ $1 \mathrm{~kg} a . i$ ha-1) at 3 DAS, T3-Pre emergence (pendimethalin @ $1 \mathrm{~kg} a . i \mathrm{ha} a^{-1}$ ) at 3 DAS + Hand weeding at 25 DAS, T4-Post emergence (Quizalofop-p-ethyl @ $50 \mathrm{~g}$ a. $i$ ha ${ }^{-1}$ ) at 25 DAS,T5-Pre emergence (pendimethalin @ $1 \mathrm{~kg} \mathrm{a.} \mathrm{i} \mathrm{ha-1)}$ at 3DAS +Post emergence (Quizalofop-p-ethyl @ $50 \mathrm{~g}$ a. $i$ ha ${ }^{-1}$ ) at 25 DAS, T6-Polythene sheet mulching, T7-Sugarcane trash mulching.

\section{Net monetary returns}

The net monetary return (NMR) under each treatment was determined by subtracting the cost of cultivation from GMR of each treatment. The lowest profit of ₹ 6425 was obtained when crop was not weeded throughout the crop season. The highest NMR was recorded application of pre-emergence (pendimethalin@ $1 \mathrm{~kg}$ a.i ha-1) at 3 DAS + post emergence (Quizalofop - p- ethyl @ $50 \mathrm{~g}$ a. i ha ${ }^{-1}$ ) at 15 DAS with ₹ 25427 followed by Sugarcane trash mulching of ₹ 22050 followed by pre emergence (pendimethalin $1 \mathrm{~kg}$ a.i ha-1) at 3DAS + Hand weeding with return of $₹ 18870$.

\section{Benefit cost ratio}

It refers to net monetary gain over each rupee of investment. The benefit cost ratio as affected by different treatments has been given in Table 7. B:C ratio was higher under the application of application

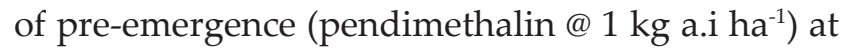
3 DAS + post emergence (Quizalofop - p- ethyl @ $50 \mathrm{~g}$ a. i ha-1) at 15 DAS registered the $\mathrm{B}: \mathrm{C}$ ratio of 2.05:1 followed by Sugarcane trash mulching (1.91:1) and pre-emergence (pendimethalin $1 \mathrm{~kg}$ a.i ha ${ }^{-1}$ ) at 3 DAS + Hand weeding recorded the $\mathrm{B}: \mathrm{C}$ ratio of 1.7:1.

\section{CONCLUSION}

The pulse growing farmers are not following the proper weed management practices at the critical stages of crop growth due to lack of awareness, negligence and scarcity of manpower during cropping period. In addition, they are practicing the hand weeding method of weed management but in non critical stages of crop, which results improper crop growth and development and viral disease infestation. In addition, weather conditions will not favour to operate timely hand weeding due to wet field condition during Kharif season. The delayed weed management leads to reduction of yield. Under these circumsatces, application of herbicides will be an better alternative for effective weed control at critical stages. In the present study also revealed that application of pre-emergence (pendimethalin@ $1 \mathrm{~kg}$ a.i ha ${ }^{-1}$ ) at 3 DAS + post emergence (Quizalofop-p- ethyl @ $50 \mathrm{~g}$ ai ha ${ }^{-1}$ ) at 15 DAS $\left(\mathrm{T}_{5}\right)$ recorded significantly the higher seed yield (1004 kg ha-1) with $1875 \mathrm{~kg} \mathrm{ha}^{-1}$ of stover yield with the B:C ratio of 2.05 in black gram cultivation.

\section{ACKNOWLEDGMENTS}

The authors would like to thank the organization and also the information received through students and farmers. We would also like to acknowledge organization to permit us to takeup study for betterment of farming community.

Conflicts of Interest: The authors are declared that there was no conflict of interest for this article.

\section{REFERENCES}

Begum, G. and Rao, A.S. 2006. Efficacy of herbicides on weeds and relaycrop of blackgram. Indian Journal of Weed Science, 38(1\&2): 145-147.

Chattha, M.R.J., Muhammad and Mahmood, T.T. 2007. Yield and yield components of black gram as affected by various weed control methods under rainfed conditions of Pakistan. Int. J. Agri. Biol., 9(1): 114-119.

Chand, R., Singh, N.P. and Singh, V.K. 2003. Effect of weed management practices on productivity of late planted urdbean during kharif season. Indian Journal of Pulses Research, 16(2): 163-164. 
Chand, R., Singh, N.P., and Singh, V.K. 2004. Effect of weed control treatments on weeds and grain yield of late sown blackgram. Indian Journal of Weed Science, 36(1\&2): 127-128.

Gurdeep Singh, Parmeet Singh and Lal, S.B. 2008. Effect of integrated weed management on growth and yield of summer mung. Environment and Ecology, 26(1A): 269-271.

Gurjar, M.S., Kushwah, S.S., Jain, V.K. and Kushwah, H.S. 2001. Effect of different herbicides and cultural practices on growth, yield and economics of soybean (Glycine max (L. ) Merrill). Agriculture Science Digest, 21(1): 1316.

Halvankar, G.B., Varghese, P., Taware, S.P. and Raut, V.M. 2005. Effect of herbicides on weed dynamics and yield of soybean. Journal of Maharashtra Agricultural Universities, 30(1): 35-37.

Kumar, S. and Angiras, N.N. 2005. Efficacy of pendimethalin under different planting methods of blackgram (Vigna mungo). Indian Journal of Weed Science, 37(3/4): 216-219.

Kushwah, S.S. and Vyas, M.D. 2005. Herbicidal weed control in soybean (Glycine max (L.) Merrill). Indian Journal of Agronomy, 50(3): 225-227.

Mallikaarjuna, G.B., Bhairappanavar and Jayadeva, H.M. 2010. Performance of maize urd bean inter cropping as influenced by weed management. Mysore J. Agric Sci., 44(2): 276-282.

Meyyappan, M. and Kathiresan, R.M. 2005. Integrated weed management in maize+black gram intercropping system. Indian Journal of Weed-Science, 37(3/4): 209-211.

Mishra, J.S. and Chandra Bhanu. 2006. Effect of herbicides on weeds, nodulation and growth of Rhizobium in summer blackgram (Vigna mungo). Indian Journal of Weed Science, 38(1 \& 2): 150-154.

Moolani, M.K. and Sachan, P.L. 1996. Studies on crop weeds competition. A review. Indian Journal of Agronomy, 11: 372-377.

Parvender, S.S., Sukhvinder and Virender, S. 2006. Effect of weed management practices on yield and economics of mungbean in Kandi region of Punjab. Indian Journal of Pulses Research, 19(2): 263-264.
Patel, R.B., Patel, B.D. and Parmar, J.K. 2014. Combination of imazethapyr with other herbicides against complex weed flora in blackgram. In: Extended summary: Biennial conference on emerging challenges in weed management held at DWSR, Jabalpur from 15-17 February, pp.115.

Rajput, D. Kavita Bhale, V.M., Kamble, A.S. and Sonawane, R.K. 2014. Response of herbicides and cultural practices on growth and yield of blackgram. In: Extended summary in Biennial conference on emerging challenges in weed management. 15 - 17 February 2014, DWSR, Jabalpur. p 96.

Raman, R. and Krishnamothy, R. 2005. Nodulation and yield of mung bean (Vigna radiata $\mathrm{L}$. ) influenced by integrated weed management practices. Legume Research, 28(2): 128-130

Rao, A.S. 2008. Effect of time and dose of post -emergence herbicides on Echinochloa colona (L. ) Linn. In black gram grown as relay crop. Indian Journal of Weed Science, 40: 3/4): 165-168.

Reddy, M.D. Reddy, C.N. and Devi, S. 2000. Effect of herbicides on weed growth and crop performance in rice-black gram cropping system. Indian Journal of Weed Science, 32(3/4): 169-172.

Sardana, V., Singh, S. and Parvendar, S. 2006, Efficacy and economic of weed management practices in Blackgram under rainfed condition. Indian Journal of Weed Science, 38(1 \& 2): 77-80

Sharma, M. and Yadav, M.S. 2006 effect of weed management practices on urdbean and associated weeds. Indian Journal of Weed Science, 38(1\&3): 143-144.

Singh, B.G. and Krishana Mohan. 1994. Physiological effects of pre emergence herbicides in mung bean (Vigna radiata L., Wilczek). Annals of Plant Physiology, 8(1): 79-82.

Velayudham, K. 2007. Economics of practicing integrated weed management in blackgram. Madras Agricultural Journal, 94(1/6) : 55-60.

Vikas, B., Singh, B., Randhawa, J.S. and Singh, J. 2004. Relative efficacy and economics of integrated weed management in black gram under semi - humid climate of Punjab. Indian Journal of Weed Science, 36(3/4): 276-277. 